\title{
"Felicidade é entrar num vestido P": o culto ao corpo na sociedade urbana contemporânea
}

\author{
Mirela Berger
}

resumo Este artigo reflete sobre o processo contemporâneo de culto ao corpo, em especial, entre mulheres de classes média-alta e frequentadoras da academia de ginástica Cia Athlética, procurando entender por que o corpo assume um lugar privilegiado nas referências simbólicas de nossa cultura. Mostra que as mulheres pesquisadas veem seus corpos como "meios" importantes de interação social, obtenção de status, inserção no mercado de trabalho, valorização de si, etc. No final, aborda, ainda que rapidamente, alguns paradoxos do culto ao corpo, como os distúrbios alimentares.

palavras-chave Representaçóes corporais. Culto ao corpo. Mídia. Distúrbios alimentares.

\section{Introduçáo}

O presente artigo sintetiza dados e reflexões discutidos em minha tese de doutorado, defendida em 2006 no PPGAS da Universidade de São Paulo. A pesquisa foi realizada com 80 mulheres, todas praticantes de atividades físicas e frequentadoras da academia de ginástica Cia Atlhética. Os objetivos centrais eram perceber e compreender como as mulheres brasileiras urbanas, a partir de 1990, pensavam a construção de sua autoimagem, quais modelos corporais exerciam influência neste processo e quais as técnicas corporais empregadas pelas mulheres para atingir seus objetivos. Outro ponto central da pesquisa era refletir sobre o fenômeno do culto ao corpo, procurando entender suas origens e implicações para a autoestima das mulheres pesquisadas, e é sobre este último ponto que o artigo em questão se detém.

Dessa maneira, embora o presente trabalho não se concentre nas linhas analíticas que discutem profundamente as questóes do gênero e da classe social, as mesmas não deixaram de perpassá-lo, até porque, como salienta Lauretis, "a partir do momento em que assinalamos o ' $\mathrm{F}$ ' num formulário, ingressamos oficialmente no sistema sexo-gênero, nas relaçôes sociais de gênero, e fomos 'engendradas' como mulheres, isto é, não apenas os outros que nos consideram do sexo feminino, mas a partir daquele momento nós passamos a nos representar como mulheres" (Lauretis, 1994, p. 220). Assim, embora ciente de toda a polêmica que envolve as discussóes de gênero, e mesmo sabendo que cada vez mais os homens aderem a vários suportes da cultura do corpo, a opção por entrevistar somente mulheres deveu-se aos seguintes motivos: a facilidade de acesso ao universo feminino e o interesse em delineá-lo com a maior abrangência possível; a nítida percepção de que as mulheres estavam mais dispostas a conversar com uma mulher sobre aspectos ligados ao corpo do que os homens, etc. É preciso salientar, também, que como o lócus do trabalho foi a academia de ginástica Companhia Athlética (unidade Shopping Morumbi), retentora de um público-alvo abas- 
tado, as reflexôes foram balizadas pelo eixo "classe social"; dessa maneira, as consideraçóes aqui realizadas valem apenas para uma parcela da população: de modo algum refletem toda a especificidade dos body-builders e, menos ainda, das mulheres de modo geral.

Quanto à faixa etária, a mais representativa é composta de mulheres entre 29 e 39 anos; em segundo lugar, apareceu a faixa que vai de 40 a 50 anos; quanto à escolaridade, a pesquisa descobriu que $16 \%$ tinham superior incompleto, $55 \%$ superior completo e $18 \%$ cursam pós-graduação, representando $89 \%$ das entrevistadas com nível superior. Já no que é referente ao mercado de trabalho, aproximadamente dois terços $(67,5 \%)$ da população estudada exerce a profissão, enquanto o restante, $32,5 \%$, encontra-se fora do mercado de trabalho, vivendo de renda ou sendo sustentadas pelos maridos. A coleta de dados dividiu-se em aplicação de questionários fechados e realização de entrevistas semidirigidas gravadas com as mesmas mulheres que responderam ao primeiro, bem como observação participante ${ }^{1}$.

Por fim, uma última consideração importante antes de passarmos para a análise. Se em alguns momentos o tom dado à discussão pode parecer homogeneizar o universo das mulheres body-builders, tal fato se deve à surpreendente consonância no discurso das entrevistadas, bem como da bibliografia consultada, que, guardadas as devidas proporçóes, parece conter um alto grau de consenso. É claro que as mulheres entrevistadas têm poder de questionar o culto ao corpo, de discuti-lo, de propor alternativas e mesmo de perceber paradoxos. Procurei contemplá-los na tese, mas para as curtas dimensóes de um artigo, preferi trabalhar com dados mais gerais. Foi surpreendente para mim descobrir que $88 \%$ da amostra percebem a existência de um culto ao corpo; que $96 \%$ atribuem à mídia a principal responsabilidade por este processo; que $56 \%$ conhecem alguém com distúrbio alimentar; que para 95\% a importância dada ao corpo cresceu vertiginosamente nas últimas décadas; que $72 \%$ sonham com uma ou mais cirurgias plásticas e que para $97 \%$ a prática da malhação interfere muito na autoestima. Ainda assim, precisamos ter em mente que estes dados valem apenas para o universo pesquisado e quiçá para outras academias de luxo, mas não para todas as academias e, menos ainda, refletem a opiniáo das mulheres em geral. Como antropólogos, devemos ter em mente que a diversidade, mesmo quando aparentemente temos consenso, é a pedra de toque não só da disciplina, mas da experiência humana em toda a sua riqueza.

\section{Entendendo e datando o processo de culto ao corpo}

Estar bela, malhada, sentir-se bem consigo mesma. Não ter gordurinhas sobrando. Ter um corpo rígido, cabelos e pele impecáveis. Ser admirada por sua beleza ou por seu corpo em forma. Ter um corpo perfeito. Encaixar-se nos padróes de beleza massificados. Cultuar o corpo, desejá-lo belo, mas, ao mesmo tempo, malhá-lo. Submetê-lo a esforços físicos para que ele desabroche em sua melhor forma.

Estas falas, todas nativas, apontam para um processo central das últimas décadas (19802000), que é o culto ao corpo. Embora seja quase impossível estabelecer com certeza quando as expressóes "culto ao corpo" e "cultura do corpo" apareceram pela primeira vez, numerosos antropólogos, sociólogos e historiadores vêm se utilizando destes termos para designar um comportamento no qual o corpo figura como elemento central e definidor de identidades. Mais do que ser apenas um meio, o corpo transforma-se no próprio fim, ou, como diria Maffesoli:

O que parece desconcertante atualmente é que o corpo é tomado em si mesmo; há um culto 
ao corpo que ganha cada vez mais importância na vida social. Cuida-se do corpo, constrói-se o corpo, e é neste sentido que se pode falar de um culto ao corpo como sendo uma das marcas deste hedonismo (Maffesoli, 1998).

Segundo Courtine (1995), o fato é que o corpo e o trabalho muscular estão em toda parte. Foi-se o tempo em que ele estava restrito aos estádios e ringues de luta; hoje ele aparece a todo instante pelas telas de cinema, pela televisão e, principalmente, nas ruas:

Entre a multidão de passantes, os body-builders destacam-se por sua forma de andar: braços afastados, peito abaulado, rigidez (...). O corpo do body-builder pretende tirar todo o benefício do peso no campo do olhar, saturá-lo de massa muscular. Impor-se no olhar alheio. O músculo marca. Ele é um dos modos privilegiados de visibilidade do corpo no anonimato urbano das fisionomias (Courtine, 1995, p. 82-83).

Entre as mulheres, é fácil identificar quem é ou não "malhada" pelo modo imponente com que elas andam, pelas roupas mais justas e que evidenciam os contornos e por decotes, fendas, ombros à mostra, além do olhar, normalmente sedutor e seguro, bem como pela imponência da postura. O desejo deste corpo feminino magro e definido e a cultura visual que irá se desenvolver a partir dele é muito antigo, mas explodiu nos E.U.A., definitivamente, a partir de 1980. Nessa época, ocorreu um desenvolvimento considerável do mercado do corpo magro e musculoso e do consumo de bens e serviços ligados à sua manutenção, além de todo um aparato da mídia que nos reforça o tempo todo como este corpo é desejável e necessário. Para Courtine, todas estas práticas de gerenciamento do corpo, que florescem a partir de 1980, são sustentadas por uma obsessão dos invólucros corporais: o desejo de obter a tensão máxima da pele; o amor pelo liso, pelo esbelto, pelo jovem; ansiedade frente a tudo que na aparência pareça relaxado, franzino, enrugado, pesado, amolecido; uma contestação ativa das marcas do envelhecimento no organismo (Courtine, 1995, p. 86).

No Brasil, o fenômeno do culto ao corpo explode nos anos 1990, ou seja, dez anos após seu início nos E.U.A. Esse processo de culto ao corpo não é alvo apenas dos pesquisadores: entre as entrevistadas ${ }^{2}$, em vários momentos, foi citada, de forma espontânea, a expressão "culto ao corpo", seja para criticá-lo, seja para reforçá-lo enquanto mecanismo fundamental de construção da identidade. As entrevistadas estão familiarizadas com a expressão e com o processo em si e, surpreendentemente, muitas foram precisas em datá-lo.

As mulheres entrevistadas indicaram que houve um aumento da importância dada ao corpo entre os últimos cinco e quinze anos, o que compreende o período de 1990 a $2005^{3}$, exatamente o mesmo percebido entre os pesquisadores da área. Isso se explica por várias razóes, mas, de modo geral, as mulheres entrevistadas sentem, literalmente na pele, esse desabrochar da cultura física. Muitas não faziam atividades físicas antes deste período, mas se sentiram motivadas a fazê-lo nos últimos quinze anos e/ou assistiram a outras pessoas do seu círculo de relaçôes se iniciando na "malhação". Também percebem o culto ao corpo através do aumento do número de academias, assim como pelo fato de que se exercitar e cuidar da aparência virou assunto, está na mídia, nas conversas, permeando todo o universo das entrevistadas. Percebem que a mídia aumentou, além do número de publicaçóes destinadas ao corpo, também a exibição de mulheres bonitas nas novelas e/ou em outros programas televisivos. Quando questionadas se elas percebem um processo de culto ao corpo, de imediato $88 \%$ delas afirmou 
que sim. Segundo elas, boa parte das mulheres passa a viver em função disso, procurando emagrecer e se submeter a cirurgias plásticas.

No que esse processo se diferencia da cultura física iniciada da década de 1920 ? Em vários aspectos, mas em linhas gerais, o culto ao corpo atual se diferencia do passado principalmente em termos de ênfase, pois é claro que a beleza sempre foi importante, mas ganha uma dimensão avassaladora após os anos 1980. Vários motivos explicam esse fenômeno: a globalização; as melhorias técnicas na área de cosméticos, alimentos e aparelhos de ginástica; os recursos imagéticos e sua penetração em todas as classes sociais; o fato de a mulher cada vez mais ingressar no mercado de trabalho e ter renda e autonomia para se dedicar a investimentos estéticos, dentre outros.

Não é nosso objetivo aqui explicar exaustivamente todos os motivos do culto ao corpo, mas, sim, debater alguns deles, além de mostrar como o corpo vai assumir um lugar privilegiado nas referências simbólicas de nossa cultura. Segundo Del Priori,

Uma radicalização compulsiva e ansiosa a empurrou nos últimos dez anos, e a segue empurrando para a tríade abençoada pela mídia: ser bela, ser jovem, ser saudável! Graças à supremacia das imagens, instaurou-se a tirania da perfeição física (Del Priori, 2000, p. 79).

Analisaremos, a partir de agora, as principais justificativas das mulheres pesquisadas para explicar o fenômeno do culto ao corpo. São elas: importância do momento presente, da técnica e do esforço individual; importância do corpo na conquista de parceiros sexuais e no mercado de trabalho; exposição e desnudamento do corpo; existência de modelos de beleza rígidos que culminam no culto à perfeiçáo física; excessiva cobrança da sociedade pela beleza e influência da mídia e da moda ${ }^{4}$.

\section{Importância do Momento Presente, da Técnica e do Esforço Individual}

Uma, entre várias entrevistadas, afirma:

Você vê pessoas que tomam anabolizantes, pelo corpo, e se esquecem da saúde, porque náo pensam no que vai fazer mal, só pensam no agora, ficar bem bonita agora. (Mulher 24, estudante de educação física, 18 anos, superior incompleto).

Esta fala aponta para dois pontos importantes: o primeiro, que o culto ao corpo está ligado ao que Maffesoli (1998) chamou de presenteísmo, ou seja, a demasiada primazia do presente na contemporaneidade - vive-se para o agora, para o instante imediato; a tradição, táo rica no período anterior à contemporaneidade, é descartada, e o futuro está demasiado longe para se pensar nele. Nas conversas informais com as entrevistadas, muitas reforçaram que quando questionadas sobre as consequências de atitudes como regimes extremos, bronzeamento artificial, uso de drogas para emagrecer, afirmam que não vale à pena se preocupar demais com os seus efeitos nocivos em longo prazo, pois o importante é estar bonita agora. $\mathrm{O}$ outro ponto que merece destaque é que a entrevistada aponta para um dado fundamental para se entender a modernidade e o processo de culto ao corpo, qual seja, a questão da técnica:

As salas de musculaçáo, se você for ver, o que tinha antigamente e o que tem hoje, hoje você tem aparelhos que você póe a chave e ele te diz o que você tem que fazer, a tecnologia auxilia muito (Mulher 14, professora de ginástica, 34 anos, superior completo).

Courtine (1995) reforça a importância da técnica e do comportamento regrado na construção corporal do body-builder após os anos 1980. Segundo ele, o desenvolvimento do mer- 
cado do músculo e do consumo de bens e serviços destinados à manutenção do corpo, além de toda uma tecnologia do suor, são alguns dos itens que diferenciam as práticas atuais das antigas práticas de musculação e que, nesse sentido, marcam um processo de culto ao corpo diferente de outros processos ligados ao corpo no passado. Segundo ele, a tônica da atualidade é que é preciso 'sofrer se distraindo: a sofisticação eletrônica do material quer fornecer novos meios para favorecer a constância exigida pela disciplina e combater a dor do esforço e também o tédio da rotina' (Courtine, 1995, p. 84).

Sylvie Malisse (apud Del Priori, 2000, p. 160), afirma que, a partir dos anos 1970, junto com as bonecas Barbie chegaria ao Brasil o body business, ou seja, máquinas e técnicas do corpo que promoveriam um marketing de vivências corporais, e passaríamos de uma estética feminina a uma ética feminina - ética que obrigaria a mulher a responsabilizar-se por seu próprio envelhecimento e a consumir produtos e técnicas para evitá-lo. A mulher passa a ser responsabilizada por sua imagem e cobrada por ela, reforçando assim estereótipos e construçóes de gênero. Ela incorpora que uma das suas responsabilidades, enquanto mulher, é ser bonita. É claro que os homens não estão imunes a esse universo, fazendo uso, inclusive, de técnicas corporais como o uso de anabolizantes para parecerem mais fortes, o que também reforça imperativos ligados ao gênero. Mas para alguns autores, tais como Goldemberg (2004), Del Priori (2000), Laurettis (1994) e Perrot (1998), as mulheres ainda são mais cobradas do que os homens com relação aos imperativos de beleza e juventude.

Esta associação entre técnica e marketing corporal é visível na academia de ginástica Cia Athlética, pois há um grande investimento no aparato técnico, em especial, dos equipamentos de ginástica em si (esteiras, transport, bicicletas, aparelhos de musculação). Para exemplificar, as máquinas de exercício têm entrada para uma chave própria de cada aluno, que registra todas as informaçóes sobre o que ele deve fazer e o que efetivamente foi feito, além da supervisão constante dos instrutores. Tudo isso parece nos dizer que a tecnologia para a obtenção de um corpo perfeito está disponível, você só não a utiliza se não quiser. $\mathrm{E}$ pior, também só não conquista um corpo perfeito se não quiser. Desta forma, atribui-se à conduta do aspirante a portador do corpo perfeito consegui-lo ou não. A estética se vale do discurso da ciência e se legitima por ele.

Outro pilar que sustenta a ideologia do corpo perfeito é que o mesmo passa pelo esforço do indivíduo, ou seja, a ênfase de que o indivíduo, sozinho, utilizando-se de aparelhos, pesos, muita ginástica, alimentação e produtos químicos, pode construir seu corpo ideal, tão veiculado e reforçado pela mídia. Melhor dizendo, ele não precisa e nem deve "se conformar com o que Deus lhe deu”, já que, com seu esforço, ele pode corrigir o que não corresponde ao padrão cultural de sua época e lugar. Estamos na era da tecnologia do suor e, através dela, acredita-se que podemos escolher o corpo que queremos ter: "Você pode se tornar a pessoa que sonha ser', dizem os body-builders. Você pode desafiar ao mesmo tempo o inato e o adquirido e fazer de você um outro" (Fussel, 1991, p. 73). A ideologia que se vende aos adeptos do culto ao corpo é que o indivíduo, somente ele, é quem vai prestar contas ao olhar crítico e hierarquizante de seus pares, além de se submeter ao escrutínio da fita métrica, da balança e do espelho em um processo que exige dele uma conduta ascética, racional e individualista. E mais, além de ser produto do esforço individual, passa pela conquista de um corpo que só ele vai ter e, posteriormente, da forma física como veículo de afirmação de status, conquista de parceiros sexuais em mesmo nível estético e inserçâo social. Para se atingir 
a forma ideal e expor o corpo sem constrangimentos, é preciso investir na força de vontade e na autodisciplina, como reforçam as revistas de estética. É como se a possibilidade de construir um corpo ideal, com o auxílio dessa tecnologia do suor, se confundisse com a construção de um destino, de uma obra.

\section{Importância do corpo na obtenção de parceiros afetivos e no mercado de trabalho}

Outro motivo fundamental para que haja um culto ao corpo é, segundo as entrevistadas, a importância que o corpo assumiu na obtenção de parceiros afetivos e melhores empregos. Somente $11 \%$ declararam que a aparência física influi pouco; a maioria foi enfática quanto à importância da aparência na escolha de parceiros:

Ah, acho que todo mundo tenta dizer que náo, mas no fundo você não vai querer uma pessoa horrível, acho que é legal a personalidade, mas também não pode ser uma pessoa muito feia (Mulher 5, professora de ginástica, 22 anos, superior completo).

Vale lembrar que hoje o contato corporal entre os parceiros é muito mais intenso e direto do que nas décadas anteriores. Na década de 1920, um casal que iniciasse um namoro tinha pouco contato físico antes do casamento, sendo vigiado por parentes, e conversava-se muito antes de um envolvimento físico, ao contrário do que ocorre hoje. Se há algumas décadas as afinidades morais, intelectuais e de assuntos comuns compensavam detalhes da aparência, hoje isso é mais difícil de ocorrer. As pessoas jovens se encontram em "baladas", nas quais a aparência figura como primeira mediadora. É de praxe "ficar" logo no primeiro encontro, sendo, portanto, mais difícil "abstrair" o corpo do outro. Desta maneira, os padróes corporais acabam tendo maior importância que tinham no passado, pois funcionarão como "iscas", atraindo ou não potenciais parceiros.

Percebemos também nos depoimentos que a beleza é hoje uma espécie de capital simbólico que agrega representaçóes de sucesso e de status, ou, segundo Peirce (s/d), é um "indicador" de pessoa bem-sucedida. Todos querem ser belos e/ou ter ao lado pessoas belas. Hoje, ter um corpo malhado é sinal de status, e isso se acirra num cenário em que os casamentos não são mais arranjados como eram na aristocracia, nem dependem tanto de nomes e sobrenomes. Em tempos de culto ao corpo, apela-se para a beleza. $\mathrm{Ou}$, como diria uma das entrevistadas: "Se você anda com uma pessoa bonita as outras pessoas te olham de uma maneira diferente" (Mulher 10, estudante, 26 anos, superior incompleto).

Numa época em que vigoram as tiranias da aparência, ser 'apenas' boa mãe e esposa não basta, cabendo às mulheres se adequarem aos padrôes estéticos estabelecidos. Assim, parte do prestígio social da mulher advém de sua aparência e, parecido com o que Saffioti ${ }^{5}$ afirmou, mas invertendo os termos, os homens também se beneficiam da imagem física de suas esposas ou companheiras, configurando uma atitude de status reflexa: o embelezamento das mesmas confere prestígio aos homens, pois, ao circularem com elas nos meios sociais que cobram beleza, eles se afirmam como viris (conquistaram e mantiveram mulheres bonitas), bem-sucedidos (capazes de manter economicamente a casa e ainda permitir que a mulher possa "se cuidar" - e 'se cuidar' será interpretado pelas mulheres como 'estar bonita'), como atesta um depoimento (escolhido entre vários):

Meu marido paga minha academia, me dá total apoio, porque é bom também pra ele ter uma mulher bonita ao lado, todo mundo gosta $(\mathrm{Mu}-$ lher 14, professora de educação física, 34 anos, superior completo). 
Em muitos casos, a academia é paga pelo marido, e se a mulher 'dona de casa' usufrui da renda aferida pelo marido, ela também ingressa/permanece na relação com outros capitais - todos eles construídos culturalmente e nas relaçôes de gênero: as aptidóes para ser boa mãe, administrar a casa e ser bela.

A pesquisa questionou também a importância da aparência física no mercado de trabalho. Para 59\% das entrevistadas, há uma associação direta entre aparência e mercado de trabalho, ou, como elas disseram, quando não é decisiva ${ }^{6}$, ao menos abre portas. As falas ressaltam que ter corpo e rosto bonitos é tão importante quanto ser competente, pelo menos num primeiro momento. Escolhe-se o candidato também se levando em conta sua apresentação pessoal: assim, duas pessoas com a mesma formação não têm necessariamente a mesma chance - o de melhor aparência vence a disputa. Se o trabalho envolver atendimento ao público, a beleza se torna ainda mais importante, pois se acredita que ela vai atrair o cliente, que depois pode se interessar pelo produto. Se o trabalho desenvolvido estiver ligado ao corpo, como no caso dos professores de ginástica, esteticistas, nutricionistas, terapeutas corporais, etc., ele é fundamental: muitas entrevistadas disseram que o corpo é o próprio cartão de visitas, e que ter um corpo malhado lhes confere legitimidade profissional.

Mas, de todos os motivos que tentam explicar o culto ao corpo, os mais significativos se relacionam aos seguintes temas: exposição do corpo, existência de modelos de beleza, culto à perfeição, competição e, sobretudo, a mídia.

\section{Exposiçáo do corpo}

A intensa exposição do corpo foi largamente citada e $53 \%$ da amostra julgaram-na exagerada; $43 \%$ julgaram-na intensa, o que totaliza 96\%:
Conforme foi se mostrando o corpo, foi diminuindo a roupa, vai se cuidando mais do corpo, na praia os biquínis estão cada vez menores, mostra-se cada vez mais o corpo, então você tem que estar em ordem pra que todo mundo olhe pra você e veja e digam "olha, tá toda trincada" (Mulher 7, artista plástica, 39 anos, pós-graduação).

De fato, basta observarmos ao redor para constatarmos que as roupas estão cada vez menores, e não apenas as roupas de banho; as roupas cotidianas diminuíram progressivamente de tamanho. Se nos remetermos aos séculos anteriores ao século XX, essa mudança é radical. Mas, mesmo se reduzirmos o universo da comparação ao último século, temos o advento da minissaia nos anos sessenta e, nos anos setenta, o biquíni de duas peças que, utilizado por Leila Diniz, chocou boa parte da sociedade da época, mas que comparado aos biquínis de hoje seria considerado gigantesco. Dos anos 1990 para cá as calças de cintura baixa fazem sucesso e os tamanhos diminuem nas lojas. A indústria da moda diminuiu e apertou o tamanho das roupas, ao mesmo tempo em que associou a elas uma aura de beleza: quando a mulher vai às compras, se precisar de tamanhos um pouco maiores, precisa recorrer a lojas especializadas. Segundo Proust, 'mostra-se cada vez mais o corpo: cada etapa desse desnudamento parcial começa provocando certo escândalo, depois se difunde rapidamente e acaba se impondo. Mostrar os seios e as coxas deixa de ser indecente. O corpo não é apenas assumido e reabilitado: é reivindicado e exposto à visão de todos' (Proust, 1993, p. 105).

Além disso, há uma correlação entre o fato de o Brasil ser um país tropical e ser maior aqui a exposição do corpo, o que incentiva mais seu culto, como bem indicam as mulheres:

Eu vou muito aos E.U.A. e vejo gente mais gorda, só que lá a preocupação com o corpo e com

cadernos de campo, São Paulo, n. 19, p. 69-90, 2010 
a autoestima não é tanto como no Brasil, talvez por ser um país tropical, onde as mulheres estâo com menos roupas, mais expostas, então eu sinto que a autoestima cresceu com relação ao corpo, a valorização do corpo, isso é uma coisa muito forte do Brasil (Mulher 16, publicitária, 36 anos, pós-graduação).

O que constatei é um círculo vicioso: como as roupas estão menores e o corpo está na ordem do dia, ele fica mais exposto. Ora, o que é mais visível, pelo menos na nossa cultura, deve ser mais bonito, entáo a maior exposiçáo do corpo faz com que ele se transforme em alvo das atençóes e, portanto, num objeto cultuado. Cultua-se a aparência e/ou beleza e investe-se em mecanismos para se alcançar o padrão de corpo veiculado, seja através da malhação, seja através de dietas. Só que, uma vez alcançado esse formato de corpo, o que fazer com ele? Escondê-lo? Pelo contrário: na medida em que o corpo vai ficando mais bonito, você também quer expô-lo mais. Esse é um dos pontos centrais da cultura do corpo e central para nossa reflexão. Como a identidade é sempre um mecanismo construído no embate de relaçóes, o que eu sou e o que eu penso de mim não existem independentemente do modo como os outros me veem; e, ao fazê-lo, não só me veem, mas me avaliam. O corpo malhado, então, é fundamental para a autoestima das pessoas, para que elas se sintam, como dizem as entrevistadas, "bem consigo mesmas". No entanto, isso só alcança sua real importância se ele for visto e admirado pelos outros, vindo daí a necessidade de exposição.

Se é verdade que a exposição leva a um culto ao corpo, o contrário também é verdadeiro: faz parte da própria ideologia do culto ao corpo que o mesmo é plástico, passível de ser remodelado com exercícios e dietas e que, quando isso acontece, o corpo passa a ser passível de exposição. Aliás, isso é ainda mais complicado, pois para boa parte das entrevistadas o corpo só pode ser exposto se estiver malhado:

À medida que o corpo melhora, a gente vai descobrindo [no sentido de tirar a roupa] mais ele. Quando a gente começa, quer esconder a barriga, mas depois, você vê que já não tem mais barriga, você vai se expondo. A gente começa com aquela camisetona grandona, aí você vai diminuindo o tamanho dos tops e se mostrando mais (Mulher 69, comerciária, 45 anos, superior completo).

É interessante notar que em todas as falas aparece a mesma ideia, ou seja, de que o corpo deve estar pronto para ser exibido, no sentido de estar "malhado" o suficiente. Esta visão do corpo é profundamente diferente da ideia professada por Bakhtin (1987), que considerava o corpo medieval em sua essência inacabado, contendo em si imperfeiçóes e falhas, e estando, da mesma forma que o mundo, em permanente construção. Ele não era limitado por uma fachada externa perfeita. Nada mais distante da concepção atual que postula que o corpo deve ser exposto só quando estiver bonito o suficiente para isso. A ideia de "pronto" remete aqui à ideia de perfeito, como veremos a seguir.

\section{Modelos de beleza e culto à perfeiçáo}

Outro dado que aparece nas entrevistas e que confirma a dificuldade de estabelecer a ordem dos fenômenos é a questão da perfeição, muitas vezes citada para se explicar o próprio culto ao corpo.

Ah, muita cultura da perfeição, muita mesmo. Ainda mais em quem faz ginástica, quer que a pessoa que esteja do lado seja perfeita, hoje em dia está todo mundo malhando, até de madrugada, tenho amigos que trabalham o dia todo e são triatletas, e muitos cobram das esposas que trabalham, que têm filhos e náo conseguem ir à 
academia, cobram muito delas porque são gordinhas, têm celulite. As mulheres são cobradas para estarem bem. O que influencia muito isso é o mercado publicitário, que cada vez mais investe em mulheres bonitas para poder divulgar os seus produtos (Mulher 14, professora de ginástica, 34 anos, superior completo).

Podemos perceber que, no processo de culto ao corpo, meio e fim se confundem, tamanha é a supremacia dos modelos estéticos. É preciso estar bela, ou até mais do que bela, perfeita. E o que é ser perfeita? A entrevistada citada acima diz que os próprios maridos cobram a perfeição das esposas, mas essas são gordas, têm celulite. Então, por oposição, a mulher perfeita é a magra, sem celulite. E também sem estrias. Com seios duros, levantados e grandes. Com o corpo malhado e tonificado, com nádegas arredondadas e firmes. Cabelos impecáveis, rosto sem rugas. Pele uniforme, lisa. Cintura fina. Ou seja, mulheres com um corpo e um rosto que nunca envelhecem, apesar da idade; não perdem as formas, mesmo depois de vários filhos; cujos cabelos são sedosos e brilhantes, mesmo com o passar dos anos. A cultura da perfeição dissolve as marcas do tempo e proclama o triunfo da técnica e da padronização sobre o eu: se o seio caiu, levante-o com plásticas, você pode ter um seio melhor do que tinha aos 18 anos. Com botox, você se livrará das marcas de expressão. Você malhou bastante, mas não conseguiu uma cintura de pilão? É só tirar as costelas! O corpo da atriz de televisão é o que você sempre quis? É possível com plásticas. Engordou por causa dos filhos e a rotina não permite exercícios? Faça de madrugada. As mulheres por mim entrevistadas são compelidas a alcançar um padrão estético que muitas vezes não tem nada a ver com a estrutura do seu físico, ou com sua idade: é o padrão das modelos. A beleza está na mídia, na moda, nos outdoors e, mais que um direito, é hoje um dever. A feiúra constrange, envergonha. Isola. E como os parâmetros estão cada vez mais altos, qualquer detalhe já é o bastante para que sejamos vistos como não perfeitos. Ser saudável e bonita não basta, é preciso ser perfeita. Mesmo que para isso seja preciso recorrer a plásticas. Algumas entrevistadas reforçam a existência desses padróes estanques de beleza e a influência dos mesmos no processo de culto ao corpo:

Com certeza você tem hoje um padrão estético que é um padrão físico (...) que faz com que a maioria de nós, mulheres, alguns tem uma graça divina que não se deixam tocar por isso, mas a maioria das pessoas de alguma forma se sente tocada. Se você não está dentro deste padrão que na verdade é retocado pela mídia, você está excluído. (Mulher 30, professora de comunicação, 40 anos, pós-graduação).

Há uma evidente descartabilidade de pessoas que pareçam envelhecidas ou "fora de esquadro", assim como uma luta constante para dissimular os indícios corporais que atestem esse afastamento da juventude ou do padrão que caracteriza o corpo perfeito. Talvez essa busca do corpo "perfeito", aliada à percepção de que ele possa ser algo construído, sejam algumas das razóes não só da preocupação de uma faixa etária mais jovem com o corpo, mas inclusive para o aumento da frequência da terceira idade nas academias de ginástica. Featherstone (1992) afirma que a cultura do consumidor prende-se a uma concepçáo autopreservacionista do corpo que encoraja os indivíduos a adotarem estratégias instrumentais para combater a deterioração e a decadência, e agrega a essa concepção a noção de que o corpo é um veículo do prazer e da autoexpressão. Nesse sentido, Debert (1999) afirma que os idosos possuem maior disponibilidade para o consumo, e que parte desse potencial é aplicado à transformação corporal, já que esta auxiliaria na construção de 
uma autoimagem e de um reflexo mais positivo de si para a sociedade envolvente. De toda forma, disciplina e hedonismo se combinam na medida em que as qualidades do corpo são tidas como plásticas e os indivíduos são convencidos a assumir a responsabilidade da sua própria aparência. A publicidade, os manuais de autoajuda e as receitas dos especialistas em saúde estão empenhados em mostrar que as imperfeiçóes do corpo não são naturais nem imutáveis e que, com trabalho corporal disciplinado, pode-se conquistar a aparência desejada; as rugas ou a flacidez se transformam em indícios de lassitude moral e devem ser tratadas com a ajuda de cosméticos, da ginástica, das vitaminas, da indústria do lazer.

Sabino (s/d) afirma que nas academias brasileiras o consumo de anabolizantes e a prática constante de exercícios físicos fazem parte do processo de construção ritual da pessoa, cuja lógica central passa pela transformação física do corpo. Falar em "ritual" remete-nos à obra de Turner, O Processo Ritual (1974), em que o autor nos mostra que uma das chaves centrais para o entendimento das culturas reside nos ritos, já que os mesmos são indícios para a compreensão de pensamentos, sentimentos e relaçóes entre os nativos e o seio de suas comunidades. Entre os vários ritos sociais, destacam-se os chamados "ritos de passagem", ou seja, "ritos que acompanham toda mudança de lugar, estado, posiçáo social de idade" (Van Gennep, 1960, apud Turner, 1974). Tais ritos caracterizam-se por três fases: 1) separação, 2) margem ou limem e 3) agregação. A primeira fase marca o afastamento do "neófito" de um determinado grupo ou ponto fixo na estrutura social. A segunda marca o processo de transição, quando este inicia o lento aprendizado das regras, valores e linguagem do grupo ao qual quer ascender. A terceira fase consuma a passagem e reintegra o indivíduo no grupo, fazendo com que o mesmo assuma os direitos e deveres de sua nova posição.
Ou seja, dentro do grupo dos malhadores, podemos perceber claramente as fases descritas por Turner: a mulher, ao ingressar em uma academia, deseja construir um corpo magro e levemente musculoso, para se separar e se contrapor ao grupo das "não malhadas" e "gordas". Ela quer sentir-se integrada e aceita em uma sociedade que valoriza a forma física como referencial de status e sucesso. Ela tentará, a partir de então, adequar seu corpo à forma correspondente dos novos papéis que deseja assumir. Assim, ela se separa do grupo das sedentárias, o que corresponde à primeira fase do processo ritual, qual seja, a "separação". Durante a segunda fase, ela se encontra num processo de "liminariedade". Sendo que ainda é uma neófita, precisa aprender as regras do grupo, que, no caso, envolve praticar exercícios com regularidade, consumir produtos específicos, manter uma dieta alimentar, conhecer o nome das aulas, enfim, socializar-se no campo da musculação e dos outros setores das academias. $\mathrm{O}$ processo é permeado de rituais que envolvem vestimentas, condutas, dialeto próprio, enfim, toda a manipulação de um universo instrumental e simbólico, que não está livre nem mesmo da já consagrada "eficácia simbólica" (Lévi-Strauss, 1991), ou seja, do poder, que é próprio do rito, de atuar sobre a realidade agindo sobre a representação que estes indivíduos fazem dela. Quem é adepto de exercícios físicos sabe que a simples realização do treino previsto já dá ao praticante a sensação de ter melhorado seu corpo, ainda que ele saiba que os resultados não são tão rápidos assim. Mas, ao menos, ele sente que fez a sua parte quanto ao corpo: é como dizem as entrevistadas, "uma missão cumprida". Ao menos, ele não poderá ser rotulado de "fraco", "desleixado": ele "luta" para mudar o seu corpo e empenha-se para isso, o que, no limite, lhe confere até fibra moral, segundo os valores postulados pela ideologia do corpo perfeito. $\mathrm{Na}$ terceira 
fase, "agregação", ela é consagrada ao papel de "malhadora": suas atitudes e seu próprio corpo atestam que ela agora é uma "nova mulher, que não se conformou com o que Deus lhe deu, correu atrás, batalhou, ficou mais bonita e mais segura" (mulher 70, artista plástica, 30 anos, pós-graduação). O corpo perfeito lhe conferirá uma nova identidade, um novo lugar no seio da comunidade à qual ela pertence.

\section{Competiçáo e Cobrança Social}

A preocupação com o corpo, a importância que ele alcançou no mercado de trabalho, nas relações afetivas e na relação das mulheres consigo próprias e com os outros, além da existência de padrôes corporais muito evidentes, introduzem no sistema duas variáveis importantes: a competição e a cobrança social. Muitas mulheres se referiram a elas ao falar do culto ao corpo:

É insatisfação pessoal, as pessoas começam a se cuidar, a ficar mais bonitas, existe um clima de competição, você vê hoje uma pessoa bonita, com um corpo legal, por que que eu não vou ficar também? Então isso mexe com o ego, alimenta aquela coisa de você querer ficar parecido, consequentemente o culto ao corpo que eleva a autoestima. (Mulher 46, jornalista, 42 anos, superior completo).

O corpo se transforma, ele próprio, em uma mercadoria rentável, passível de ser desejado, exposto, comprado: já que a modernidade instaura um culto à mercadoria, nada mais coerente que o fato de ter um corpo perfeito adquira tanta importância quanto ter bens. $\mathrm{O}$ corpo se torna um capital, mais um elemento no circuito das trocas econômicas e sociais: a competitividade do mundo dos negócios se transfere para o corpo. Até porque, como este corpo perfeito custa dinheiro, ele não é para todos: é só para aqueles que podem pagá-lo.
O corpo instaura assim, no rol das diferenças, mais uma, a estética. Num cenário como o nosso, em que a falta de dinheiro pode levar ao descrédito social e a noção de cidadania passa pela inserção no mercado de consumo, inferiorizando as pessoas mais pobres e privando-as, muitas vezes, do acesso à saúde e à alimentação, instaura-se mais uma clivagem, a da aparência física. Essa, inclusive, é indissociável da própria clivagem econômica, pois o corpo perfeito custa dinheiro, requer alimentação diet - sempre mais cara que a comum -, cirurgias plásticas, tratamentos estéticos caros, roupas de ginástica de griffe. Através do corpo reafirma-se mais uma exclusão social: o corpo malhado nas academias, como comentou Boltanski (1979), é diferente do corpo do trabalhador, que é um meio para a atividade e não um fim em si mesmo. Nas camadas superiores da hierarquia social, diminui o volume do trabalho manual em favor das atividades intelectuais, fazendo com que os indivíduos alterem o sistema de regras que regem suas relaçóes com o corpo, dedicando a ele cuidados mais atentos e específicos. Uma maior preocupação com a manutenção da forma física e da valorização da "graça" e flexibilidade corporais é mais comum e intensa nos segmentos abastados do que nas camadas menos favorecidas economicamente. A valorizaçâo da magreza é mais intensa nas camadas superiores. Nos segmentos subalternos, para os quais a força muscular desponta como um atributo de maior valor, muitas vezes o magro é visto como "fraco". A diferença na terminologia é interessante: pessoas de maior peso são chamadas de "gordas" entre as classes sociais mais abastadas e de "fortes" entre os menos favorecidos. Daí que duas pessoas da mesma corpulência física serão consideradas magras entre os pobres e gordas entre os ricos. Além do mais, o trabalho muscular aqui não está ligado ao trabalho rotineiro dos trabalhadores braçais, não está a serviço do sustento familiar, 
mas se configura como um marcador de classe e da maior capacidade de dispender tempo e dinheiro com cuidados estéticos.

Portanto, se o corpo de uma pessoa for mais malhado do que o de outra, em termos hierárquicos, a primeira ganha. Ou, como diz Del Priori,

A indústria cultural ensina às mulheres que cuidar do binômio saúde-beleza é o caminho seguro para a felicidade individual. É o culto ao corpo na religião do indivíduo em que cada um é simultaneamente adorador e adorado. Mas o culto não é para todos. $\mathrm{O}$ tal corpo adorado é um corpo de 'classe'. Ele pertence a quem possui capital para frequentar determinadas academias, possui personal trainer, investe no body fitness; este corpo é trabalhado até adquirir as condições ideais de competitividade que lhe garanta assento na lógica capitalista. Quem não o modela está fora, é excluído (Del Priori, Op.cit, p. 92).

Não importa se ganho de status, de dinheiro, de empregos ou de sucesso afetivo, o que importa é que através do corpo malhado a pessoa pode afirmar-se como superior à outra, mais competente e plenamente realizada. $\mathrm{O}$ corpo bonito pode fornecer sucesso econômico, mesmo para aquelas que não são modelos, e a aparência define o sucesso ou fracasso pessoal. Ele vende uma imagem de positividade e de sucesso que pode se converter em ganhos efetivos. Ou, então, ele também pode fazer vender cosméticos, roupas, cirurgias, etc. $\mathrm{Na}$ medida em que se cria uma necessidade, que é ter o corpo perfeito, é preciso também disponibilizar os meios para alcançá-lo, e esses fazem a economia girar. A ideologia do corpo perfeito cria demandas e, num país capitalista, demandas são vitais para o sucesso da economia. Pode-se comprar tudo hoje em dia, de cosméticos a prótese de glúteos. Vivemos em uma permanente vitrine de corpos e não demorará o dia em que compraremos, junto com os produtos de limpeza no supermercado, uma prótese de silicone, como afirmou uma entrevistada:

Então, a gente pode pensar em vários fatores, políticos, econômicos, sociais, culturais, no econômico: o corpo entra em uma linha de produto de consumo, atualmente as mulheres compram peito, compram bunda, compram a perda de culote, o corpo hoje é bem de consumo. (Mulher 50, psicóloga, 26 anos, pós-graduação).

Quando falamos no processo de culto ao corpo, percebemos que a presença de modelos corporais e a busca da perfeição caminham juntas com a competição, mas também com a cobrança social, assinalada em várias falas:

É uma cobrança social. Antigamente não fazia parte do assunto, ninguém perguntava: 'você faz exercício?'. Hoje em dia faz parte, 'você faz academia?' Faz tão parte do dia a dia das pessoas que é cobrado. Muitas pessoas começaram a fazer exercícios por causa disto. Se ela fala 'ah eu não faço ginástica', ela já é vista de outra forma: 'nossa, essa aí não faz nada'. As mulheres estão muito neuróticas, elas não fazem isto por causa do marido, é entre elas. Elas competem, o que é muito ruim (Mulher 51, economista, 34 anos, superior completo).

Como percebemos nas falas, malhar virou tema de conversas. Se você não pratica algum esporte, ou não faz atividade física, corre o risco de ser olhada pelos outros de modo depreciativo, como se a sua falta de atividade física refletisse certa lassidão moral, uma preguiça condenável em tempos de exaltação das formas e dos movimentos. Há uma cobrança para que, ao menos, façamos nossa parte quando se trata do corpo, e isso significa fazer exercícios, ou, como disse Perrot: 'No espaço público a mulher tem quase um dever de beleza (...). A burguesia 
reproduz este modelo segundo uma divisão dos papéis sexuais que delega às mulheres a ostentação do luxo e do lazer' (Perrot, 1998, p. 22).

Vale perguntar: no caso de nossas mulheres, cobrança de quem? Eu diria que generalizada dos maridos ou companheiros, das outras mulheres, de si mesmas e da sociedade como um todo. Algumas são mais explícitas quanto à cobrança dos maridos ou companheiros, afirmando que começaram a malhar por causa disso:

Eu faço porque não tem jeito, eu sou obrigada. Se eu pudesse estar em casa sentada eu estaria, não estaria aqui. Eu não gosto de atividade física. Meu marido é um grande incentivador meu a não parar (Mulher 19, artista plástica, 51 anos, superior completo).

Outro relato é muito emblemático para se pensar a questáo da cobrança: Mulher 13, de 59 anos, mudou de uma das unidades da Cia Atlética, a unidade da rua Kansas ${ }^{7}$ para a unidade do Shopping Morumbi, e ela comenta sobre o peso que a beleza e o corpo têm de acordo com estes dois locais:

Com relação aos padróes da mídia, primeiro tem o aspecto cronológico, eu mesmo não revelava minha idade [59], tinha vergonha... Aí eu mudei da Kansas, vim para cá e falei a minha idade e até me permiti engordar alguns quilinhos. Aqui existe uma cobrança muito grande neste sentido, é onde a 'Feiticeira' treina, então existe um culto ao corpo lá excessivo, tanto da parte dos homens, como das mulheres. Ali os mortais, os normais, saem de lá, você não encontra uma gorda treinando lá de jeito nenhum, você se sente mal de ficar gorda lá, onde só tem gente bonita. Beleza lá é uma obrigação (Mulher 13, psicóloga, 59 anos, pós-graduação).

Ou seja, o corpo, a magreza, a juventude passaram a ter tanta importância na nossa cul- tura que inibem as pessoas de procurarem uma academia de ginástica se elas não estão perto da perfeição! É uma cultura claustrofóbica, que ao mesmo tempo em que nos empurra para a necessidade de "malhar", também exclui do mundo das "malhadas" aquelas que ainda não chegaram lá, mas que estão procurando "entrar em forma”. É como se houvesse academia para "sarados" e academias para não "sarados", unidades corretas para uns e não para outros!

Concluindo, de táo comum, podemos dizer que o culto ao corpo já se tornou parte da nossa cultura e nos suscita a pensar sobre ele, sob pena de sermos por ele tragados. O culto do eu exige, como ressaltaram Elias (1990) e Rodrigues (1999), uma atenção maior ao peso das convenções sociais e do teatralismo artificial sobre as sensaçóes imediatas, tornando o indivíduo menos resistente às pressóes externas, que antes eram exercidas sobre toda a sociedade e agora passam a ser exercidas sobre cada um de nós, aumentando nossa vulnerabilidade à mídia e às opiniôes alheias. $\mathrm{Ou}$, como afirmou Rodrigues:

O indivíduo independente, autônomo e livre, absorve água quando pensa respirar e acaba se afogando no oceano das regras de um sistema político e econômico, de uma cultura que o escraviza e que o obriga a ser exatamente assim: alguém que desempenha compulsoriamente $o$ papel de ser livre, autônomo (...). O indivíduo acaba por sentir em si o mal-estar silencioso, derivado da talvez mais hermética das prisões, aquela que se constitui quando o homem passa a ser um carcereiro de si próprio, vivendo na ilusão de ser livre. Mal-estar ruminante, que emerge inapelavelmente quando o ser humano se transforma, para relembrar as muito sábias palavras de Montaigne, em 'amo de si mesmo' (Rodrigues, 1999, p. 178-179).

Para Elias, temos uma mudança na própria estrutura da personalidade que, pressionada 
por sançóes sociais externas, desenvolve mecanismos de autocontrole mesmo quando o indivíduo encontra-se sozinho em casa: 'Impulsos que prometem e tabus e proibiçóes que negam prazeres, sentimentos socialmente gerados de vergonha e repugnância entram em luta no interior do indivíduo's (Elias, 1990, p. 189). Ou seja, os indivíduos vão interiorizando o controle das pulsôes, o tom das prescriçóes passa a ser cada vez mais imperativo quanto ao autocontrole. Recontextualizando para o culto ao corpo, podemos resumir afirmando que muitas mulheres são livremente obrigadas a fazer ginástica, cultuar a magreza e a "malhação", sonharem com próteses de silicone e de caberem no tamanho "P". Como um veneno que nos contamina pelos olhos sem que o notemos, a cultura do corpo infiltra-se em nós e, ao mesmo tempo, nos seduz e provoca.

\section{Consideraçóes Finais}

Embora não seja possível discutir neste artigo a questão da mídia (ver Berger, 2007) gostaria, a título de encerramento, de fazer algumas consideraçôes, já que uma das principais evidências que a pesquisa constatou é que a comunicação é um dos pilares do atual culto ao corpo, embora autores como Lucien Sfez (1996) proclamem a substituição do culto à informação por uma "religiáo" biogenética, calcada na "utopia do corpo". Acredito, ao contrário de Sfez, que a comunicação está vivíssima e é a grande aliada, ao mesmo tempo veiculadora, dessa utopia do "corpo perfeito". O desafio está em procurar descobrir como esses dois pilares muitas vezes se entremeiam, precisam disso para sobreviver e dizem muito a respeito da concepçáo de pessoa e dos valores centrais à nossa sociedade. Para 96\% da amostra a mídia influi no processo de culto ao corpo. As entrevistadas mencionam a leitura de revistas ligadas à aparência física, como Boa Forma, Dieta Já, entre outras, e assi- nalam que a mídia auxilia a propagar o culto ao corpo. Um dado interessante sobre a influência da mídia e que foi comentado de maneira espontânea por três entrevistadas é que o culto ao corpo veio na esteira dos grupos de pagode e axé, como o É o Tchan, e com a valorização do corpo semidesnudo e malhado das personagens Tiazinha e Feiticeira. Em todos esses casos, o corpo era claramente um fetiche, no sentido de ser exposto como perfeito e alvo dos desejos masculinos. Criou-se um clima de erotização que passava pela exposiçáo de corpos "malhados" e que contribuiu para a divulgação de um padrão de corpo que, por sua vez, invadiu as casas via televisão ou através de revistas como a Playboy, a Sexy e a Boa Forma. Aliás, justamente na época de explosão destes grupos e das personagens citadas, Joana Prado saiu na capa da revista Boa Forma, cuja chamada de capa era "O feitiço do corpo perfeito". Em outra capa, desta vez da Revista Corpo, temos a chamada "Fique gostosa como elas", com a exibição da modelo Luma de Oliveira, também muito citada como referencial de beleza, enfatizando que considera a plástica uma aliada: isso nos dá a clara associação entre modelos/plásticas/mídia, que por sua vez exerce forte impacto sobre o imaginário de mulheres comuns.

Featherstone (1995) diz que a centralidade da manipulação comercial das imagens, mediante publicidade, mídia, exposiçōes, performances e espetáculos da trama urbanizada da vida diária determina, portanto, uma 'constante reativação de desejos por meio das imagens' (Featherstone, 1995, p. 100). De tanto ver o corpo malhado exposto, seja no dia a dia, seja na mídia, acostumamo-nos a desejá-lo e, de tanto desejá-lo, ele se tornou vital para nós.

As imagens têm um papel novo e central na cultura de consumo. A concentração, a densidade, a abrangência da produção de imagens na sociedade contemporânea nos empurra para uma sociedade qualitativamente nova, o mun- 
do simulacional, no qual se aboliu a distinção entre realidade e imagem, estetizando-se a vida cotidiana. Como dizia Debord (1992), tudo se transforma em espetáculo, ou seja, numa relação entre pessoas, mediada por imagens. Segundo ele 'o espetáculo é a afirmação da aparência. Ele se apresenta como uma enorme positividade, indiscutível e inacessível. Não diz nada além de 'o que aparece é bom, o que é bom aparece" (Debord, 1992, p. 16).

No que se refere à cultura do corpo na contemporaneidade, a imagem é central. Primeiro, porque toda cultura do corpo passa por imagens reais do corpo, projetadas como espetáculos; segundo, porque as imagens veiculadas pelos meios de comunicação são indissociáveis deste processo de desejar e construir um corpo ideal.

No universo dos body-builders proliferam revistas específicas destinadas aos cuidados com o corpo, tais como Boa Forma, Dieta-Já, Corpo, etc. É evidente também o quanto a preocupação com o corpo tomou conta de várias outras revistas, como Veja, Época e de jornais diários como Folha de S. Paulo e Estado de São Paulo. As revistas citadas são prenhes em imagens que priorizam corpos considerados bonitos. Além disso, são comuns fotos que contrastam situações chamadas de "antes" e "depois". As fotos do "antes" são imagens corporais de mulheres que eram "gordas e infelizes"; já as do "depois" mostram imagens dessas mesmas mulheres, agora "magras e bonitas, através do produto " $\mathrm{X}$ " ou da clínica tal". Vincula-se felicidade à beleza e, por sua vez, beleza à magreza. Essas imagens são cruciais na construção e reafirmaçáo de alguns modelos corporais, bem como da representação de gênero a eles associada. Segundo Lauretis (1994), os termos para uma construção de gênero ocorrem através de tecnologias (como o cinema, a televisão, as revistas) e discursos institucionalizados com o poder de 'controlar o campo do significado social e assim, promover e implantar representaçóes de gênero' (Lauretis, 1994, p. 228).
Também foi demonstrado pela pesquisa de Goldenberg e Ramos que a exigência da boa forma não se limita às atrizes ou modelos:

"Por intermédio do cinema, da televisão, da publicidade e de reportagens de jornais e revistas, a exigência acaba atingindo os simples mortais, bombardeados cotidianamente por imagens de rostos e corpos perfeitos" (Goldenberg; Ramos, 2002, p. 26). Tais imagens induzem à correlação entre obter o corpo perfeito e alcançar a felicidade. A publicidade surge neste processo como uma espécie de operador totêmico, e as formas perfeitas como totens midiáticos.

Para os body-builders, o corpo representa, ao mesmo tempo, um projeto em si, uma vez que a identidade e autoestima parecem passar cada vez mais pela aquisição de um corpo perfeito e uma marca de distinção, representante de um estilo de vida, para os outros, o que nos remete a Bourdieu (1979), segundo o qual a preferência por certos bens culturais funciona como um marcador de classe. Assim, a pequena burguesia surgida com a modernidade diferenciou-se de camponeses e agricultores adotando uma visão de mundo progressista, que incluía um rigoroso controle do corpo. Empregando o conceito de habitus como um conjunto de disposiçóes que determinam os gostos e caracterizam camadas sociais, ele emprega tal conceito para designar as disposiçōes inconscientes, esquemas classificatórios, preferências explícitas e evidentes para a noção que o indivíduo tem da adequaçáo e validade de seu próprio gosto por certas práticas e bens culturais. Neste caso, o habitus burguês operaria não só no plano da cognoscibilidade cotidiana, mas estaria inscrito no corpo, manifestando-se no seu tamanho, forma, volume, nos modos de sentar, comer e beber, no grau de estima pelo corpo. Bourdieu chega a afirmar que "o corpo é a materialização do gosto de classe: o gosto de classe está corporificado" (Bourdieu, 1979, p. 56).

Acredito, portanto, que se torna impossível falar de identidade feminina entre as mulheres 
$84 \mid$ Mirela Berger

urbanas sem nos remetermos às relaçôes que estas estabelecem com seus corpos. O corpo será, ao mesmo tempo, suporte e substrato da identidade: seja na conquista de parceiros, ou de melhores empregos, a autoestima, fundamental para a construção de uma identidade positiva, passa pelo corpo. Ainda que em outras esferas a mulher tenha adquirido sucesso e prestígio, aos olhos dos outros e de si mesmas, se elas não conquistarem também um corpo ao menos bonito, serão consideradas em déficit. Segundo dados colhidos em minha pesquisa de campo, para $96 \%$ da amostra fazer exercícios físicos foi central para a autoestima, e para $84 \%$ os exercícios engendraram outros cuidados com a estética.

No entanto, se há seduçóes no processo de culto ao corpo, também há perigos. O corpo-signo que despontou em minha pesquisa foi o corpo magro e malhado (eleito o ideal para $63,75 \%$ da amostra), conquistado pela associação entre regimes e exercícios. Mais da metade da amostra afirmou fazer regimes, e o restante fez reeducação alimentar. $79 \%$ já tomaram medicação para emagrecer, confirmando o dado de que o Brasil é líder mundial no consumo de anfetaminas. Sempre me espanta que em nome da beleza, da perda de peso, homens e mulheres aceitem se submeter aos efeitos colaterais dos remédios para emagrecer. Temem um infarto, empenham-se em fazer tudo que a medicina aconselha, fazem atividade aeróbica e diminuem a ingestáo de gorduras. Mas, deliberadamente, através dos remédios para emagrecer, elevam os batimentos cardíacos a ponto de ter insuficiência respiratória e/ou infarto. A maioria deles contém anfetamina, que vicia em dias e é muito nociva para o organismo, gerando desequilíbrio hormonal, bem como taquicardia e depressão. É sabido também que provoca danos no cérebro e ocasiona distúrbios como anorexia e bulimia. Contudo, em nome de alguns quilos a menos, aceitam os riscos. $\mathrm{O}$ que ocorre é que, na verdade, a leitura é outra. Não se trata de meros quilos perdidos: trata-se de fazer as pazes com o espelho e, portanto, consigo mesma. Trata-se de sentir-se integrada, aceita. Trata-se de ascender, via corpo, ao grupo das bonitas e bem-sucedidas. Trata-se de existir, numa cultura em que beleza e magreza se associam, sendo pré-condição de felicidade. Talvez, por isso, a pesquisa tenha constatado que $10 \%$ da amostra são portadoras de anorexia e bulimia e 56\% conhecem pessoas com estes distúrbios (ver Berger, 2006; 2008 b).

Um relato é emblemático das dificuldades geradas pelos distúrbios alimentares:

Eu já sabia que tinha anorexia há anos, mas demorei para aceitar o diagnóstico. Só parei de tomar anfetaminas quando fiquei perto do infarto. Vivia doente, recusava qualquer comida, praticamente vivia de água. Cheguei a pesar 42 $\mathrm{kg}$, mas me achava gorda, queria mais remédio, queria malhar muito mais, mas não tinha forças. Todos diziam que eu estava horrível de magra e muitas amigas ameaçavam me internar. (Mulher 68, professora universitária, 36 anos, pós-graduação).

Outro aspecto que nos auxilia a entender a preocupação com a magreza é que há uma intensa cobrança social, dirigida até mesmo às crianças, pela aquisição desse modelo corporal. Um relato de uma máe cuja filha é um pouco mais cheinha ilustra a questão:

Os parentes dizem: 'Diminui a quantidade de comida do prato dela', 'ela já tá gorda, você vai dar doces para ela!?'. E ela só tem três anos de idade! (Mulher 32, comerciante, 33 anos, superior completo).

Diante desta tirania da magreza podemos entender por que mulheres com um peso "normal” se sintam gordas e queiram se livrar dos 
"quilos a mais" como quem se livra de um estigma. Segundo uma pesquisa do Hospital das Clínicas de São Paulo, a faixa de idade de meninas vitimadas pela anorexia caiu de 12-14 anos para 7-8 anos, momento em que a criança ingressa no ensino fundamental. Isso se deve à comparação com as coleguinhas e à maior capacidade de discernir os modelos, sem falar nos programas infantis, que também são apresentados por mulheres magras, malhadas.

Outro dado alarmante que nos obriga a avaliar a responsabilidade dos meios midiáticos nos distúrbios alimentares é que as interessadas em perder peso rapidamente podem se valer da internet, rede em que há comunidades que náo apenas incentivam a perda de peso, mas defendem a bulimia e a anorexia como um estilo de vida e fornecem dicas, tais como: "Não comece a tentar vomitar usando toda a mão, basta o dedo bem fundo na garganta"; "Você não deve comer sem se sentir culpada"; "Você não deve comer algo que engorda sem se punir depois"; "Ser magra é mais importante que ser saudável"; "Você nunca está magra demais. Ser magra é a coisa mais importante do mundo". Há até apelidos carinhosos para as doenças: a anorexia é chamada de "Ana" e a bulimia, de "Mia". Segundo duas revistas que divulgaram a existência desses sites, IstoÉ (25/10/2002) e Veja (11/02/2004), estima-se que no Brasil bulimia e anorexia afetem 100 mil adolescentes, dos quais $90 \%$ sáo garotas.

Para Philippe Perrot (1984), a mulher magra foi mais do que moda, foi o desabrochar de uma mística da magreza, uma mitologia da linha, uma obsessáo pelo emagrecimento, tudo isso temperado pelo uso de roupas fusiformes (Perrot, apud Del Priori, 2000, p. 66), fenômeno nascido na Europa e indissociável do ingresso feminino no mundo do exercício físico, seja sobre bicicletas, nas quadras de tênis, nas aulas de dança, e isto já nos anos 1920. O corpo deveria ser esbelto, leve e delicado. Inicia-se a per- seguição e desprestígio do embonpoint, os quilos a mais, ainda que discretos. Começamos a fase, segundo Lipovetsky (1997), da cultura lipófoba, o horror a tudo que é mole, relaxado, gordo, e sobre os obesos recairá uma suspeita e um estigma moral, como confirma Fischer (1995):

A fonte principal do paradoxo é que a imagem do gordo é profundamente ambivalente (...). Através de nossos corpos passamos significados corporais muito profundos. Um dos mais importantes é o seguinte: a corpulência traduz aos olhos de todos a parte de comida que nós nos atribuímos, isto é, simbolicamente, a parte que tomamos para nós, legitimamente ou náo, na distribuição da riqueza social. Nosso corpo é um signo imediatamente interpretável por todos de nossa adesão ao vínculo social, de nossa lealdade às regras de distribuiçáo e reciprocidade. Uma suspeita pesa, portanto, sobre os gordos. Mas se não podem emagrecer, eles têm uma possibilidade de se redimir desta suspeita: precisam proceder a uma espécie de restituição simbólica, aceitando desempenhar os papéis sociais que se esperam deles (Fischer, 1995, p. 70).

Em vez de vítimas de suas glândulas e de sua hereditariedade, a pesquisa de Fischer revela que na maioria dos casos eles são vistos como os únicos culpados por sua condição, pois a gordura está ligada à falta de controle do apetite: sobre o gordo recai um julgamento moral. E o inverso é verdadeiro: ser magro é, por oposiçáo, ser controlado, e nossa sociedade valoriza o controle das pulsóes, mais ainda se ele servir ao fim, hoje nobre, da construção do corpo perfeito. Sobre o gordo recai o estigma de ser sedentário, e isso, numa cultura que tem valorizado ao extremo a atividade física, só faz aumentar a culpa sobre o gordo.

Em minha pesquisa, várias mulheres citaram uma discriminaçâo sobre o gordo, como mostra o depoimento a seguir: 
$86 \mid$ Mirela Berger

A sociedade condena as pessoas fora do padrão. Tanto que existe até um trabalho com crianças, que eles tinham cartas, uma era de paraplégico, outra de débil-mental e uma carta de obesa e as crianças na faixa de 4-5 anos tinham que ler e escolher quem eles queriam que não fosse o seu amigo. $\mathrm{O}$ maior número de crianças escolheu o obeso. Então a obesidade é um fator limitante, isto com crianças que não têm conhecimento e não estão contaminadas com nada, que nós já temos conhecimento e já estamos contaminados, por informação, cultura, aspecto pessoal, eles não, eles são puros, preferem ter um amigo numa cadeira de rodas do que um amigo obeso (Mulher 45, nutricionista, 43 anos, pós-graduação).

Tudo isso nos leva a pensar que, como em qualquer processo, em especial aqueles que se desenvolvem sob as contradiçóes de uma sociedade que se pretende moderna, o culto ao corpo traz em seu âmago conquistas e retrocessos por parte dos envolvidos no processo. Se ele é positivo porque restabelece os laços das mulheres com o que há de mais individual e primário, ou seja, o corpo, também representa inúmeros perigos. A supremacia do corpo perfeito pode levar ao contrário da construção de uma identidade: ao aderir a modelos de beleza padronizados pode ocorrer uma recusa do próprio corpo, caso ele não se encaixe nos modelos fornecidos. Pode provocar, também, uma perda de identidade, no sentido de que as marcas do tempo e das próprias características genéticas podem ser apagadas através de cirurgias plásticas, dissolvendo marcas constitutivas do eu e substituindo-as por formas e feiçóes padronizadas. Pode levar, ainda, à dissolução física total, gerando distúrbios alimentares que levariam ao esfacelamento da personalidade e, em casos mais graves, à morte. Por fim, o culto ao corpo contém em si um caráter de exclusão e desconfiança com respeito àqueles que não são como o modelo hegemônico, que não se encaixam nesses padróes estéticos de nossa era'. Talvez o culto à boa forma e sua constante exibição enquanto espetáculo seja menos o reflexo de uma aparente liberaçáo física e sexual do que os indícios de uma nova moralidade, que prega a conformidade com um padrão estético específico. Algumas reportagens de jornais e revistas mostram que, para as mulheres, o problema de tirar a roupa diante de câmeras ou parceiros não está no pudor de ficarem nuas, mas no medo de não estarem com o corpo suficientemente bonito. As minhas entrevistadas confirmam: expor a barriga, usar calças de lycra coladas e na altura do púbis, os seios cobertos por tops minúsculos só depende de saber se o corpo está "malhado" o suficiente para isso, náo passa pelo pudor do corpo em si. Mesmo com relação às roupas de banho, muitas afirmaram que não têm pudor em usar biquíni tipo "fio-dental", mas que não o fazem porque não estão com os glúteos firmes o bastante para expô-los.

Em sua obra $O$ processo civilizador (1990), Elias argumentou que é possível falar em moral estética justamente no período da modernidade, que parecia apontar para uma liberdade feminina nunca antes vista. Ele cita como exemplo a evolução dos trajes de banho, mostrando que quanto mais expostos estavam os corpos, mais se exigia de homens e mulheres um autocontrole no que diz respeito às suas pulsóes, contrariamente ao que se passava quando o decoro os mantinha escondidos. Vale ressaltar que, na maioria das praias ou comunidades que adotam o nudismo, os frequentadores também se valem de regras rígidas, punindo aqueles que permitem o afloramento das pulsóes fora dos códigos estabelecidos. Ou seja, momentos de aparente relaxamento das regras ocorrem na verdade dentro de contextos em que alto grau de controle é esperado. Sendo assim, a aparente liberação do corpo, a ênfase de que o indivíduo pode ter o corpo que quiser ter, os investimentos constantes na produçấo do eu, podem su- 
gerir seu inverso, apontando para um processo civilizador.

E como a ambiguidade parece ser indissociável do processo de culto ao corpo, adquirir o corpo "malhado" ou "perfeito" conduz à inclusão da mulher no rol das mulheres felizes, desejadas, de sucesso. No entanto, como os parâmetros estáo muito altos, por mais que o corpo esteja "malhado", nunca é o suficiente, nunca as mulheres se parecerão com a moça impecável dos comerciais de cerveja, de roupas, de cosméticos, de pasta de dente, de tudo. De tâo distante e inalcançável, o modelo leva à frustração, à negação do próprio corpo, à depressão, até porque nós, cientistas sociais, o percebemos enquanto modelo, ou seja, algo que está apenas no plano ideal; muitas mulheres, no entanto, o veem enquanto realidade, e lutam persistentemente para alcançá-lo. Goldenberg (2004) observa que a preocupação com a aparência e com a juventude se tornou uma obsessáo entre as cariocas, provocando uma permanente insatisfação com o próprio corpo, dado que comprovei em minha pesquisa, pois $90 \%$ das mulheres entrevistadas estão insatisfeitas com o padrão corporal por elas alcançado. Para Goldenberg, o corpo de Leila Diniz era voltado para o prazer, para o livre exercício da sexualidade, enquanto que o corpo de muitas mulheres hoje é mutilado e controlado e, até mesmo, apesar do desvelamento do corpo, escondido, pois ele só pode ser mostrado se estiver perfeito. É incrível como, de fator construtor de identidades, o corpo possa ser também uma prisão, cujos carcereiros podem ser a mídia, a moda, o olhar do outro, sobretudo nós mesmos, que de táo imersos no processo não o enxergamos e, quando o fazemos, também dele não escapamos ${ }^{10}$.

A lógica do culto ao corpo, se por um lado promove mecanismos de identidade, também nos faz correr o risco de perder o valor ético das diferenças, gerando o aprisionamento e a falta de opção individual, e minando qualquer pos- sibilidade de transcendência, mesmo que este processo deva sempre ser localizado num cenário circunscrito. Voltamos, assim, a ideia weberiana (1989) da "gaiola de ferro": sobre o corpo depositam-se mecanismos de racionalidade técnica e padronização, mas sem que estes tenham destinação social humana. Eles terminam exatamente onde começam: no próprio corpo.

E a saída parece distante, pois quando a racionalidade passa a reger todas as esferas sociais (científicas, econômicas, políticas), o único espaço que sobra é o da individualidade, que se processa, entre outras instâncias, no erotismo. Mas, como haver saída no erotismo se, no caso das entrevistadas, o corpo, veículo de prazer e liberdade, é também aprisionado por uma lógica capitalista, sendo padronizado e normatizado? No limite, a cultura da perfeição, aliada ao conhecimento técnico científico das cirurgias plásticas, pode ir contra princípios éticos, incitando as mulheres a regimes e plásticas talvez desnecessárias; ou mesmo vendendo, sem se preocupar com as consequências, a ideologia e os riscos do culto ao corpo perfeito. Como ficam a ética e o respeito às diferenças quando se postulam ideais estanques, seja de credo religioso, seja corporal?

$\mathrm{O}$ que podemos concluir com relação à cultura do corpo na atualidade? Devido ao caráter polissêmico do corpo, seu conhecimento é interminável, recolocando o tempo todo tanto os limites sobre ele quanto os de nossa análise sobre suas representaçóes. Permanentemente em construçáo, processo cultural por excelência, o corpo suscita mais questóes do que respostas.

Talvez possamos ver no culto ao corpo a modernidade se realizando, com todas as contradiçôes que a caracterizam: a técnica invadindo cada vez mais o mundo privado da casa e do próprio corpo, permitindo uma mudança corporal sem precedentes, mas também prendendo homens e mulheres em templos de vidros (ou "gaiolas de ferro") moldados pornós mesmos. 
Enveredamos por um processo de constituiçáo de identidade calcado na obtenção e exposição do corpo perfeito que, ao mesmo tempo em que nos singulariza e nos diferencia dos outros, liberando nossa capacidade expressiva, também nos homogeneíza. Que liberta formas que já não precisam de suportes, sustentam-se por si só, mas que são fruto de investimentos e disciplinas constantes. Que engendra novas moralidades, mas que nos faz mergulhar cada vez mais no turbilhão de um mundo regido pela aparência que, como já destacavam Baudelaire, Benjamin e Debord, dilui as fronteiras entre realidade, arte, ficção, aparência e espetáculo.

No centro deste turbilhão, estamos nós, às vezes hipnotizados demais, às vezes encarando a esfinge e tentando encontrar sentidos no caos.

\section{"Happiness is to Fit a Small Size Dress": the Cult of the Body in Contemporary Urban Society}

absract The present article aims at considering contemporary cult of the body, especially among medium and high class women who regularly attend the fitness center Cia Athlética. It tries to understand why the body has assumed a privileged place in the symbolic references of our culture. It demonstrates that these women consider their bodies to be important instruments of social interaction, a means to obtain social status and to be integrated into the business market, self-esteem, etc. Finally, it rapidly approaches some of the paradoxes of the cult of the body, such as eating disorders.

keywords Body representations. Cult of the body. Media. Eating disorders.

\section{Notas}

1. Segundo Malinowski (1921) a participação nos eventos da comunidade precede e permite o processo analítico. Wacquant (2004) leva adiante este pressuposto e propóe que façamos uma sociologia não somente do corpo, mas a partir do próprio corpo como instrumento de investigação e vetor do conhecimento. Compartilhando destas premissas, matriculei-me na referida academia e fiz todas as aulas possíveis, o que me permitiu uma relação de confiança com minhas entrevistadas e um acesso privilegiado a informaçôes delicadas, tais como as referentes aos distúrbios alimentares e ao uso de anfetaminas e até de anabolizantes.

2. Os dados foram colhidos no período de 2000 a 2005.

3. É claro que este processo se prolongará ainda por muito tempo, mas o corte temporal foi o ano de 2005, quando foram realizadas as últimas entrevistas de campo.

4. Não analisaremos aqui a importância da mídia e da moda porque excederia os limites deste artigo. Tais itens foram desenvolvidos em Berger, 2007a.

5. A autora assinala que a mulher na sociedade de classes capitalista oscila entre aderir aos papéis construídos (e ao status associado ao segundo - que Saffioti chamou de "status reflexo do marido") de "mulher economicamente ativa" ou como "mãe de família 'ociosa' (do ponto de vista do sistema dominante de bens e serviços), que goza do status reflexo do marido" (Saffioti, 1979, p. 356).

6. Segundo informaçóes de uma comissária de bordo que trabalha para uma empresa de aviação brasileira, a direção da empresa informou aos seus funcionários, em especial, às funcionárias, que o novo uniforme seria confeccionado somente até a numeração 42 e deu um prazo de três meses para que as funcionárias acima desta numeraçáo reduzissem seu peso, sob pena de demissão ou diminuição da escala de trabalho das que não se adequassem à nova silhueta.

7. A academia de ginástica Cia Atlhética tem várias unidades dispersas por todo o Brasil, mas em São Paulo, a unidade da rua Kansas foi eleita como a predileta dos famosos, principalmente, daqueles que estão na mídia, como atores, atrizes e apresentadoras de programas televisivos e que buscam conquistar e/ou reforçar seu status.

8. Nobert Elias, em sua obra O Processo Civilizador (1990), mostra como, aos poucos, o uso do conceito de courtoise - utilizado para definir as convençóes de comportamento na corte - e as representaçóes que ele suscita foram progressivamente superados pelo conceito de civilité, até que o segundo, por volta do século XVII, assume preponderância na Europa. Começa a emergir uma crítica à voracidade, ao comer exageradamente, atitudes comparadas agora à falta de mo- 
“Felicidade É entrar num vestido P" $\mid 89$

dos atribuída aos camponeses e aos comportamentos animais: "A ascensão do conceito de civilidade nas sociedades de corte marca o início da condenação dos excessos corporais valorizados na sociedade tradicional, dentre eles a embriaguez, a comilança, a gordura. Começa a se delinear outro ideal de corpo, contido, refinado, esbelto" (Elias, 1990, p. 4).

9. Para mais detalhes sobre as possíveis consequências nefastas do culto ao corpo, ver Berger, 2008b e Berger, 2008c. Para os limites desta discussão, cito rapidamente tais questôes apenas para mostrar que o processo de culto ao corpo é paradoxal, contendo em si tanto aspectos positivos quanto negativos.

10. Para $60 \%$ das entrevistadas, ir à praia é uma situação complicada, pois seus corpos ficarão expostos sem disfarces. Uma das entrevistadas, que é professora de educação física e tem o corpo trabalhado pela ginástica (além do mais, ela tem 1,69 e $58 \mathrm{Kg}, 22$ anos), diz: "Ah, na praia eu não vou. De biquíni, jamais. Se eu tiver que ir, jogar um vôlei, eu já vou de propósito de calça, de top, ou vou de roupa normal, pra ter uma desculpa, 'ah, eu vim só pra jogar', eu já sou tímida, eu sou gordinha, então eu evito”.

\section{Referências bibliográficas}

BAKHTIN, Mikhail. A cultura popular na idade Média e no renascimento: o contexto de François Rabelais. São Paulo, Hucitec, Brasília: Editora da UnB, 1987.

BERGER, Mirela. Corpo e Identidade Feminina. Tese de doutorado - PPGAS, FFLCH, Universidade de São Paulo, 2006.

Mídia e espetáculo no culto ao corpo: o corpo miragem. Revista Sinais, n. 2, NEI (Núcleo de estudos indiciários), DCSO/UFES, 2007a.

. As chaves do templo. Revista eletrônica Ponto Urbe, vol. 2, NAU/USP, $2007 \mathrm{~b}$.

. Corpo e Identidade Feminina. Ciência \& Saúde Coletiva, v.5, volume 22, 2008 a.

. O Corpo Massacrado: Os Distúrbios Alimentares. Ciência \& Saúde Coletiva, v. 5, volume 23, 2008 b.

- Paradoxos e Contradiçóes no Processo de Culto ao Corpo. Ciência \& Saúde Coletiva, v.5, volume 24, $2008 \mathrm{c}$.

BOLTANSKI, L. As Classes Sociais e o Corpo. Rio de Janeiro: Grall, 1979.
BOURDIEU, Pierre. A Distinção. São Paulo: Difel, 1979.

COURTINE, Jean Jacques. Os staknovistas do narcisismo: body-buildinng e puritanismo ostentatório na cultura americana do corpo. In: SANT'ANA, Denise Bernuzzi. (Org.). Políticas do Corpo. São Paulo: Estação Liberdade, 1995.

DEBERT, Guitta Grin. A Reinvenção da Velhice. São Paulo: Edusp, 1999.

DEBORD, Guy. A Sociedade do Espetáculo. Rio de Janeiro: Contraponto, 1992.

DEL PRIORI, Mary. Corpo-a-corpo com a Mulher: Pequena História das Transformaçōes do Corpo no Brasil. São Paulo: SENAC, 2000.

ELIAS, Nobert. O Processo Civilizador. Rio de Janeiro: Zahar, 1990.

FEATHERSTONE, M. et alii. The Body: Social Process and Cultural Theory. Londres: Sage, 1992. Cultura de Consumo e Pós-Modernismo. São Paulo: Nobel, 1995.

FISCHLER, C. Obeso benigno, obeso maligno. In: SANT'ANNA, Denize Bernuzzi. (Org.). Políticas do Corpo. São Paulo: Estação Liberdade, 1995.

FUSSEL, San. Muscle: The Confession of an Unlikely Body-Builders. Nova York: Poseidddon Press, 1991.

GOLDENBERG, Mirian; RAMOS, Marcelo Silva. A civilização das formas: o corpo como valor. In: et al. (org.). Nu e Vestido: Dez Antropólogos Revelam a Cultura do Corpo Carioca. Rio de Janeiro: Editora Record, 2002.

Apresentação, A conversão do pesquisador e $\mathrm{O}$ corpo cativo: sedução e escravidão feminina. In: . De perto ninguém é normal. Rio de Janeiro Editora Record, 2004.

LAURETIS, Teresa de. A tecnologia do gênero. In: Influências e Impasses: O feminismo como Crítica da Cultura. Rio de Janeiro: Rocco, 1994.

LÉVI-STRAUSS, Claúde. Antropologia Estrutural Um. Rio de Janeiro: Tempo Brasileiro, 1991.

LIPOVESTSKY, Gilles. Le boom de lá beauté. In: $L a$ Troisième Femme: Permanence et Revolution du Féminin. Paris: Gallimard, 1997.

MAFFESOLI, Michel. Deixar de odiar o presente. In: . Ética e Estética na Antropologia. Florianópolis, Programa de Pós-Graduação em Antropologia Social da UFSC/CNPq, 1998.

MALINOWSKI, Bronislaw. Os Argonautas do Pacifico Ocidental. São Paulo: Abril Cultural, 1984.

PERROT, Michelle. As Mulheres ou os Silêncios da História. São Paulo: EDUSC, 2005.

Mulheres Públicas. São Paulo: Unesp,

1998.

cadernos de campo, São Paulo, n. 19, p. 69-90, 2010 
$90 \mid$ Mirela Berger

PEIRCE, Charles Sanders. O ícone, o indicador e o símbolo. In: Paulo: Editora Cultrix, s/d. Semiótica e Filosofia. São

PROUST, Antoine. Fronteiras e espaços do privado. In: ; VINCENT, Gérald. (Org.). História da Vida Privada, vol 5: da Primeira Guerra a Nosso Dias. São Paulo: Companhia das Letras, 1993.

RODRIGUES, José. Tabu do Corpo. Rio de Janeiro: Achiamé, 1983.

. O Corpo na História. Rio de Janeiro: Fiocruz, 1999.

SABINO, César. As Drogas de Apolo: O Consumo de Anabolizantes em Academias de Musculação. Rio de Janei- ro: Lugar Primeiro, s/d.

SAFFIOTI, Heleieth. A Mulher na Sociedade de Classes: Mito e Realidade. Petrópolis: Vozes, 1979.

SFEZ, Lucian. A Saúde Perfeita. Tese de doutorado. Paris, 1996.

TURNER, Victor. O Processo Ritual. Petrópolis: Vozes, 1974.

WACQUANT, Löic. Corpo e Alma: Notas Etnográficas de um Aprendiz de Boxe. Rio de Janeiro: Relume Dumará, 2002.

WEBER, Max. A Ética Protestante e o Espirito do Capitalismo. São Paulo: Livraria Pioneira Editora, 1989.

\section{autora Mirela Berger \\ Doutora em Antropologia Social / USP}

Recebido em 07/03/2010

Aceito para publicação em 20/09/2010 